\title{
Can Hydro-Priming Improve Germination Speed, Vigour and Emergence of Maize Landraces under Water
}

\section{Stress?}

\author{
T. Mabhaudhi and A. T. Modi \\ Crop Science Department, School of Agricultural Sciences and Agribusiness, Faculty of Science and Agriculture, University of \\ KwaZulu-Natal, Private Bag X01, Scottsville 3209, Pietermaritzburg, South Africa
}

Received: April 30, 2010 / Published: May 20, 2011.

\begin{abstract}
We evaluated whether hydro-priming could improve vigour characteristics and seedling emergence of local maize (Zea mays L.) landraces compared to two commercial hybrids under water stress at the University of KwaZulu-Natal, Pietermaritzburg. Seeds from local landraces were produced and characterized according to kernel colour, white (Land A) and purple (Land B), and compared to two hybrids, SC701 and SR52, which are popular amongst local farmers. Seeds from each variety were soaked in water for 0 hours (unprimed or control), 12 hours and 24 hours, and germinated in a germination chamber at $25{ }^{\circ} \mathrm{C}$ for 8 days. Parameters measured included final germination, mean germination time (MGT) and germination velocity index (GVI). Seedling emergence was performed in seedling trays, using pine bark wetted to $25 \%$ or $75 \%$ of field capacity (FC), for 21 days in a temperature-controlled glasshouse (25 ${ }^{\circ} \mathrm{C}$ day; $15{ }^{\circ} \mathrm{C}$ night; 60\% RH). Parameters measured included final emergence, mean emergence time (MET), root and shoot lengths, and leaf area. Priming landraces for 12 and 24 hours reduced MGT by $9 \%$ and 7\%, respectively, compared to 5\% in hybrids for both 12 and 24 hours priming. GVI of landraces was improved by 40\% following 12 hours of priming. GVI of hybrids was $11 \%$ and $7 \%$ slower than landraces after priming seeds for 12 and 24 hours, respectively. Priming seeds for 24 hours improved emergence at 25\% FC. Priming seeds for 24 hours reduced MET for all varieties. Priming seeds for 12 and 24 hours increased leaf area by $33.8 \%$ and $29 \%$, respectively. Hydro-priming seeds for 12 and 24 hours, respectively, improved GVI, reduced MGT and improved emergence and MET of maize landraces under water stress. Performance of hybrid seeds remains superior to that of landraces even after seed treatment to improve germination and vigour. The positive response of landraces to seed treatment, and improved performance under water stress conditions, suggest that there is a need to identify genes for vigour in landrace maize.
\end{abstract}

Key words: Emergence, germination, hybrids, hydropriming, landraces, water stress.

\section{Introduction}

Good crop establishment is essential for efficient water use [1] and is a major constraint to crop production in the semi-arid tropics [2-4]. This is particularly true for maize (Zea mays L.) which does not tiller [5]. Good germination and emergence are important for achieving good crop establishment and maximum possible plant populations in the field, more

Corresponding author: T. Mabhaudhi, M.Sc., research fields: water-use and agronomy of underutilized indigenous and traditional crops. E-mail: tafadzwanashemabhaudhi@ yahoo.com. so under adverse growing conditions. As such, speed of germination and emergence is important for successful establishment [6].

Technology that enhances germination and emergence is thus important in mitigating deleterious effects of poor crop establishment due to drought. Such technology would allow farmers to achieve good crop stands and ultimately good yields. Seed priming is one such technology which has been developed to enhance germination characteristics of seeds [7]. Its purpose is to partially hydrate the seeds to a point were germination processes are initiated but not completed 
$[8,9]$. Primed seeds exhibit rapid germination and emergence under field conditions [10].

A variety of methods have been used to study the effect of seed priming on germination and growth rate of maize. These include osmopriming (soaking seeds in osmotic solutions such as polyethylene glycol), halopriming (soaking seeds in salt solutions), hydro-priming (soaking seeds in water), hormonal-priming and matri-priming [11-14]. Priming maize seed using polyethylene glycol (PEG) or potassium salts $\left(\mathrm{K}_{2} \mathrm{HPO}_{4}\right.$ or $\left.\mathrm{KNO}_{3}\right)$ accelerated germination in a chilling germinator $\left(10^{\circ} \mathrm{C}\right)$ [15]. Soaking seed in $2.5 \%$ potassium chloride $(\mathrm{KCl})$ for 16 hours reduced coleoptile and radicule length, while soaking seed in $20 \mathrm{ppm} \mathrm{GA}_{3}$ for 30 min improved some germination traits [16].

Hydro-priming (henceforth referred to as priming) is a simple low-cost method of seed priming that requires no sophisticated equipment and gives results which are easy to see [7]. Nagar et al. [17] observed a significant improvement in field emergency and seedling characteristics after hydro-priming maize for 16 hours. In a series of experiments, Harris et al. [3] showed that hydro-priming greatly improved establishment and vigour of upland rice, maize and chickpea, and resulted in faster development, earlier flowering and maturity and higher yields. This simple, low-cost, low-risk intervention also had positive impacts on the wider farming system and livelihoods and the technology proved highly popular with farmers [3, 18].

Maize landraces are still being grown by subsistence farmers in KwaZulu-Natal, South Africa under a rainfed system, which according to Rowland [19] is a risky environment. The risk is related to rainfall amount and distribution [7] during the time of planting. Farmers normally sow their maize either in late spring, before the onset of the rains, or with the first rains. The former crop usually suffers from a dry seedbed, resulting in poor emergence. The latter crop may suffer from rains that usually peter out early. In either case, the result is poor crop establishment leading to poor yields due to reduced plant populations.

Earlier work [20] showed that landraces may have the same viability but not vigour as hybrids since landraces were slower to germinate and emerge than hybrids. The aim of this study was to evaluate whether hydro-priming can be used to improve germination speed and emergence of local maize landraces under water stress conditions. The performance of landraces was compared to two popular hybrids, SC701 and SR52.

\section{Material and Methods}

\subsection{Planting Material}

Seed for the maize landraces was initially donated by local farmers in KwaZulu-Natal, South Africa, and multiplied at the University of KwaZulu-Natal in the previous year (2007). Maize landraces were characterized according to kernel colour, two of which were selected for this study; white (Land A) and purple (Land B). Two hybrids, SC701 and SR52, were used in the study for purposes of comparing the landraces' performance.

\subsection{Seed Priming Procedure}

Seeds were soaked in distilled water for 12 (P12) and 24 hours (P24), respectively. After soaking, the seeds were surface dried.

\subsection{Laboratory Germination}

Three replicates of 25 seeds from each variety and priming treatment were germinated between double layered, moistened paper towels [21]. The paper towels were rolled, put into zip-lock bags and incubated in a germination chamber at $25{ }^{\circ} \mathrm{C}$ [22] for 8 days. Radicule protrusion was the criterion of germination. Observations for final germination percentage, based on normal seedlings, were made according to AOSA [21] guidelines. Root and shoot length, root: shoot ratio, fresh and dry mass were measured.

Mean time to germination (MGT) was calculated according to Eq. (1) by Ellis and Roberts [23]: 


$$
\mathrm{MGT}=\frac{\sum \mathrm{Dn}}{\sum \mathrm{n}}
$$

Where:

MGT= mean germination time,

$\mathrm{n}=$ the number of seed which were germinated on day $\mathrm{D}$, and

$\mathrm{D}=$ number of days counted from the beginning of germination.

Germination speed was calculated based on Maguire's [24] Eq. (2):

$$
\mathrm{GVI}=\mathrm{G} 1 / \mathrm{N} 1+\mathrm{G} 2 / \mathrm{N} 2+\ldots+\mathrm{Gn} / \mathrm{Nn}
$$

Where:

$\mathrm{GVI}=$ germination velocity index $\mathrm{G} 1, \mathrm{G} 2 \ldots \mathrm{Gn}=$ number of germinated seeds in first, second... last count.

$\mathrm{N} 1, \mathrm{~N} 2 \ldots \mathrm{Nn}=$ number of sowing days at the first, second... last count.

\subsection{Total Soluble Sugars}

$0.1 \mathrm{~g}$ freeze-dried seed tissue was added to a test tube. To each test tube, $10 \mathrm{~mL}$ of $80 \%$ ethanol was added and homogenized for $30 \mathrm{sec}$ using Ultraturax and incubated for 1 hour at $80{ }^{\circ} \mathrm{C}$ in a water bath. Thereafter, the test tube were stored at $4{ }^{\circ} \mathrm{C}$ for 24 hours whereafter they were centrifuged $\left(10,000 \mathrm{rpm}\right.$ for $15 \mathrm{~min}$ at $\left.4{ }^{\circ} \mathrm{C}\right)$. Extract was filtered through glass wool and dried down overnight in a Savant Vacuum drier. Dried samples were diluted up to $2 \mathrm{~mL}$ by adding ultra pure water and centrifuged for 15 min and filtered through 0.4 micron nylon syringe filter into sample vials. Soluble sugars were determined using High-Performance Liquid Chromatography (HPLC) (Shimadza) as reported by Aung et al. [25, 26].

\subsection{Seedling Emergence}

Three replicates of 10 seeds from each variety and priming treatment combination were planted in seedling trays using pine bark as growing media at $25 \%$ and $75 \%$ field capacity (FC), respectively, over a period of 22 days in a temperature controlled $\left(25{ }^{\circ} \mathrm{C}\right.$, $60 \%$ humidity) glasshouse. Trays were weighed and watered at two-day intervals to maintain field capacities. Data collected included daily emergence for 14 days, leaf area, root and shoot lengths and root and shoot mass (fresh and dry).

Mean time to emergence was calculated using Eq. (3) by Bewley and Black [27]:

$$
\operatorname{MET}=\frac{\sum(f x)}{\sum f}
$$

Where MET = mean emergence time,

$\mathrm{f}=$ number of newly germinating seeds at a given time (day), and

$\mathrm{x}=$ number of days from date of sowing.

\subsection{Statistical Analysis}

Data collected was analyzed using GenStat ${ }^{\circledR}$ Version 11 statistical package. Means were separated using $\operatorname{LSD}(P=0.05)$.

\section{Results}

\subsection{Laboratory Germination}

\subsubsection{Final Germination}

Priming had a highly significant effect $(P<0.001)$ on final germination. Results for final germination showed there was a significant interaction $(P<0.05)$ between priming and variety (Table 1 ). With the exception of Land B, priming did not increase final germination in the other three varieties. Maximum germination (100\% for Land A and $98.67 \%$ for both hybrid varieties) was achieved in the unprimed treatment. For both priming treatments (P12 and P24), final germination fell by an average $8 \%$ in the hybrids compared to $4 \%$ in the landraces. Land B attained maximum germination (98.67\%) when seeds were primed for 24 hours (P24).

\subsubsection{Mean Germination Time (MGT)}

Priming had an effect $(P<0.001)$ on mean germination time (MGT). For all varieties, priming reduced MGT. There was a highly significant interaction $(P<0.001)$ between variety and priming in MGT (Table 1). Hybrids germinated faster than landraces when seeds were not primed. The effect of 
Table 1 Germination attributes of landraces (Land A and Land B) and hybrids (SC701 and SR52) for unprimed (UP), 12 hours (P12) and 24 hours (P24) seeds.

\begin{tabular}{|c|c|c|c|c|c|c|c|c|c|}
\hline & Variety & Germination & MGT & GVI & $\begin{array}{l}\text { Root length } \\
(\mathrm{mm})\end{array}$ & $\begin{array}{l}\text { Shoot length } \\
(\mathrm{mm})\end{array}$ & Root:Shoot & $\begin{array}{l}\text { Fresh mass } \\
(\mathrm{g})\end{array}$ & $\begin{array}{l}\text { Dry Mass } \\
\text { (g) }\end{array}$ \\
\hline \multirow{4}{*}{ Unprimed } & Land A & 100a & 4.7ab & $32.99 \mathrm{e}$ & 113d & $89.5 \mathrm{~g}$ & $1.265 \mathrm{abc}$ & $1.402 \mathrm{c}$ & $0.314 \mathrm{c}$ \\
\hline & Land B & 97.33abc & 4.7ab & 34.63de & 170.2ab & $139.5 b$ & 1.227abcd & $1.805 a$ & $0.304 c$ \\
\hline & SC701 & 98.67ab & $4.767 a$ & 32.79e & $135.5 \mathrm{~cd}$ & $102.8 f g$ & $1.345 a b$ & $1.498 \mathrm{bc}$ & $0.242 \mathrm{~d}$ \\
\hline & SR52 & 98.67ab & $4.5 b c$ & $38.46 \mathrm{~cd}$ & 132cd & $106 f$ & 1.252abc & $1.558 \mathrm{bc}$ & $0.379 a$ \\
\hline \multirow[t]{2}{*}{ Mean } & & $98.67^{\mathrm{a}}$ & $4.667^{\mathrm{a}}$ & $34.72^{\mathrm{b}}$ & $137.7^{\mathrm{a}}$ & $109.5^{b}$ & $1.272^{\mathrm{a}}$ & $1.566^{\mathrm{b}}$ & $0.3097^{\mathrm{b}}$ \\
\hline & Land A & 93.33bc & 4.3de & 46.84a & $114.5 \mathrm{~cd}$ & 163.5a & $0.721 \mathrm{e}$ & $1.895 \mathrm{a}$ & $0.323 b c$ \\
\hline \multirow{3}{*}{ P12 } & Land B & $92 \mathrm{c}$ & $4.233 \mathrm{e}$ & $48.35 a$ & $109.4 d$ & 111.4ef & 0.983cde & $1.601 \mathrm{~b}$ & $0.298 \mathrm{c}$ \\
\hline & SC701 & 94.67abc & 4.367d & 44.43ab & $191.7 \mathrm{a}$ & $133.9 b c$ & $1.444 a$ & $1.934 a$ & 0.373ab \\
\hline & SR52 & 86.67d & $4.4 \mathrm{~cd}$ & 39.85bc & $122.7 \mathrm{~cd}$ & 128.4bcd & 0.974de & $1.586 \mathrm{bc}$ & $0.408 \mathrm{a}$ \\
\hline \multicolumn{2}{|l|}{ Mean } & $91.67^{\mathrm{C}}$ & $4.325^{\mathrm{b}}$ & $44.87^{\mathrm{a}}$ & $134.6^{\mathrm{a}}$ & $134.3^{\mathrm{a}}$ & $1.03^{\mathrm{b}}$ & $1.754^{\mathrm{a}}$ & $0.3503^{\mathrm{a}}$ \\
\hline \multirow{4}{*}{ P24 } & Land A & 93.33bc & 4.367d & 40.17bc & $123 c d$ & 123.8cde & $1.012 \mathrm{~cd}$ & $1.599 b c$ & $0.314 \mathrm{c}$ \\
\hline & Land B & 98.67ab & 4.3de & $49.12 \mathrm{a}$ & 132.3cd & $129.4 \mathrm{bc}$ & $1.053 \mathrm{~cd}$ & $1.454 \mathrm{bc}$ & $0.297 \mathrm{~cd}$ \\
\hline & SC701 & 97.33abc & 4.3de & 48.43a & $147.7 \mathrm{bc}$ & $135.8 b c$ & 1.09bcd & $1.545 b c$ & $0.276 \mathrm{~cd}$ \\
\hline & SR52 & 82.67d & 4.467cd & 34.6de & 129.3cd & 113def & 1.147bcd & $1.489 b c$ & $0.4 \mathrm{a}$ \\
\hline \multicolumn{2}{|l|}{ Mean } & $93^{b}$ & $4.358^{\mathrm{b}}$ & $43.08^{\mathrm{a}}$ & $133.1^{\mathrm{a}}$ & $125.5^{\mathrm{a}}$ & $1.076^{\mathrm{b}}$ & $1.522^{\mathrm{b}}$ & $0.3217^{b}$ \\
\hline \multicolumn{2}{|c|}{$\begin{array}{l}\text { LSD }(P=0.05) \text { Variety } \\
\text { Priming } \\
\text { LSD }(P=0.05) \text { Priming }\end{array}$} & $\begin{array}{l}6.422 \\
3.211\end{array}$ & $\begin{array}{l}0.1206 \\
0.0603\end{array}$ & $\begin{array}{l}5.371 \\
2.685\end{array}$ & $\begin{array}{l}33.47 \\
16.74\end{array}$ & $\begin{array}{l}15.42 \\
7.71\end{array}$ & $\begin{array}{l}0.2847 \\
0.1424\end{array}$ & $\begin{array}{l}0.1988 \\
0.0994\end{array}$ & $\begin{array}{l}0.05503 \\
0.02751\end{array}$ \\
\hline
\end{tabular}

MGT = mean germination time; GVI = germination velocity index (germination speed). Numbers with different letters in the same column differs significantly at $\operatorname{LSD}(P=0.05)$.

priming on MGT was more pronounced in the landraces than the hybrids. Priming landraces for 12 and 24 hours reduced MGT by $9 \%$ and $7 \%$, respectively, compared to a reduction of $5 \%$ for hybrids in both cases.

\subsubsection{Germination Velocity Index (GVI)}

In addition, priming had a highly significant effect on germination speed, increasing GVI in all varieties. There was a highly significant interaction $(P<0.001)$ between variety and priming with respect to GVI (Table 1). Hybrids germinated $5 \%$ faster than the landraces when seeds were not primed. However, when seeds were primed for 12 and 24 hours, landraces germinated $11 \%$ and $7 \%$ faster than the hybrids, respectively. Over-all, priming seeds for 12 hours had the greatest effect on landraces, improving their GVI by $40 \%$ when compared to unprimed seeds.

\subsubsection{Germination Vigour Traits}

Furthermore, there was a highly significant interaction $(P<0.001)$ between variety and priming for germination vigour traits such as root and shoot lengths and fresh mass (Table 1). Root length for landraces fell by 20\% (P12) and 9\% (P24) as compared to the maximum root length reached when seeds were not primed. Land B, in particular was negatively affected by priming. Hybrids increased root length in response to priming. Their roots were $28 \%$ and $7 \%$ longer than the landraces when seeds were primed for 12 and 24 hours, respectively. Priming increased shoot length for all varieties. For landraces, seeds primed for 12 and 24 hours, respectively, had about $22 \%$ and $10 \%$ longer shoots than the unprimed seeds. While for hybrids, primed seeds were 25\% (P12) and 19\% (P24) longer than unprimed seeds. Overall, landraces responded better than hybrids to priming with regard to shoot length by $7 \%$ (P12) and 1.7\% (P24). Lastly, priming had a significant effect $(P<0.05)$ on dry mass. Landraces had a marginal increase $(<1 \%)$ when seeds were primed for 12 hours. Hybrids, however, increased dry mass by $25 \%$ and $8 \%$ when seeds were primed for 
12 and 24 hours, respectively.

\subsubsection{Total Soluble Sugars}

There was no significant interaction $(P>0.05)$ between variety and priming, with respect to total soluble sugars (TSS) (Fig. 1). Hydro-priming did not have a significant $(P>0.05)$ effect on TSS. Priming resulted in a decline in TSS in both hybrids and Landrace B. However, there were significant differences $(P<0.05)$ between varieties with respect to TSS. Landraces had higher TSS content compared to hybrids. Overall, based on mean values, landraces had $19 \%$ more TSS than hybrids.

\subsection{Seedling Emergence}

\subsubsection{Seedling Emergence}

There were no differences $(P>0.05)$ in seedling emergence (Fig. 2) with respect to variety, priming and field capacity. There was no significant interaction $(P>0.05)$ between the three treatment factors. SR52 was adversely affected when seeds were primed for 24 hours. Emergence improved under water stress when seeds were primed for 24 hours. There was no significant $(P>0.05)$ three way interaction with respect to mean emergence time (MET) (Fig. 3). However, there was a highly significant interaction $(P$ $<0.001$ ) between priming and field capacity (Fig. 3). MET was reduced when seeds were primed for 24 hours in all varieties (Fig. 3). Priming seeds for 12 hours improved emergence under optimum conditions (75\% FC) and not under water stress (25\% FC).

\subsubsection{Root and Shoot Length}

There was no significant three way interaction $(P>$ 0.05 ) between variety, priming and field capacity for all seedling characteristics (Table 2). With respect to root length, priming and field capacity both had significant effects $(P<0.05)$ while their interaction was also significant $(P<0.05)$ (Table 2$)$. Under water stress conditions (25\% FC), root length increased by 4\% (P24) and $16 \%$ (P12) in response to priming. In particular, landraces increased root length under water stress by 4\% (P24) and 21\% (P12). Although the interaction between priming and field capacity had no effect $(P>$

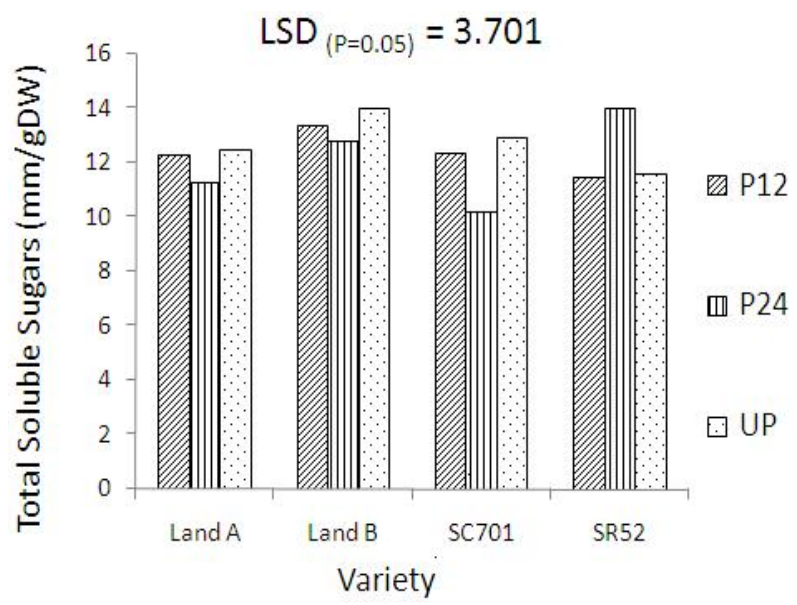

Fig. 1 Total soluble sugars concentration for landraces (Land A and Land B) and hybrids (SC701 and SR52) in response to hydro-priming seeds for 0 hours (UP), 12 (P12) and 24 hours (P24).



Fig. 2 Seedling emergence for landraces (Land $A$ and Land B) and hybrids (SC701 and SR52) grown at 25\% FC and $75 \%$ FC after seeds were either not primed or primed for 12 (P12) and 24 (P24) hours.

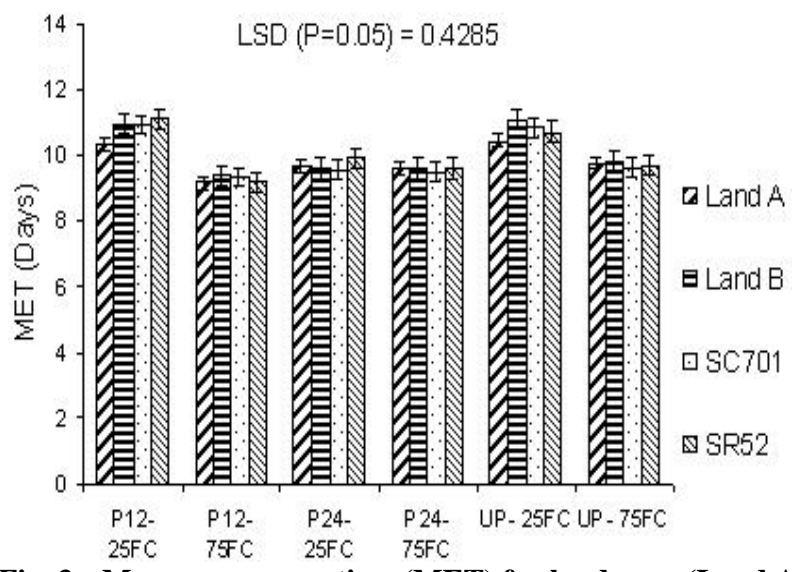

Fig. 3 Mean emergence time (MET) for landraces (Land A and Land B) and hybrids (SC701 and SR52) grown at 25\% FC and $75 \%$ FC after seeds were either not primed or primed for 12 (P12) and 24 (P24) hours. 
Table 2 Seedling characteristics of landraces (Land A and Land B) and hybrids (SC701 and SR52) at 25\% and 75\% field capacity, respectively.

\begin{tabular}{|c|c|c|c|c|c|c|c|}
\hline & Variety & $\begin{array}{l}\text { Root length } \\
(\mathrm{mm})\end{array}$ & $\begin{array}{l}\text { Shoot length } \\
(\mathrm{mm})\end{array}$ & Root: Shoot & Root DM (g) & Shoot DM (g) & Leaf area $\left(\mathrm{cm}^{2}\right)$ \\
\hline Unprimed & Land A & $55.33^{\text {cde }}$ & $204.3^{\mathrm{d}}$ & $0.276^{\text {bcd }}$ & $0.2733^{\text {bcdefg }}$ & $0.1367^{\text {abcde }}$ & $36.2^{\mathrm{def}}$ \\
\hline \multirow[t]{3}{*}{$25 \mathrm{FC}$} & Land B & $56^{\text {cde }}$ & $185^{\mathrm{d}}$ & $0.304^{\mathrm{abc}}$ & $0.2167^{\mathrm{fgh}}$ & $0.1133^{\text {bcde }}$ & $35.8^{\text {def }}$ \\
\hline & SC701 & $65^{\mathrm{abcd}}$ & $187^{\mathrm{d}}$ & $0.4061^{\mathrm{a}}$ & $0.3133^{\text {abcde }}$ & $0.0967^{\text {cde }}$ & $35.8^{\mathrm{def}}$ \\
\hline & SR52 & $45^{\mathrm{e}}$ & $177.3^{\mathrm{d}}$ & $0.2627^{\mathrm{bcd}}$ & $0.3367^{\mathrm{abcd}}$ & $0.0767^{\mathrm{e}}$ & $29.2^{f}$ \\
\hline P12 & Land A & $66.67^{\mathrm{abc}}$ & $261.7^{\mathrm{abcd}}$ & $0.2547^{\mathrm{bcd}}$ & $0.1767^{\mathrm{h}}$ & $0.1533^{\mathrm{abcd}}$ & $51.9^{\text {bcde }}$ \\
\hline \multirow[t]{3}{*}{$25 \mathrm{FC}$} & Land B & $68.33^{\mathrm{ab}}$ & $224.7^{\mathrm{cd}}$ & $0.3033^{\mathrm{abc}}$ & $0.21^{\mathrm{fgh}}$ & $0.14^{\text {abcde }}$ & $45.8^{\text {bcdef }}$ \\
\hline & SC701 & $62.33^{\text {bcd }}$ & $259.3^{\mathrm{abcd}}$ & $0.2416^{\mathrm{bcd}}$ & $0.3967^{\mathrm{a}}$ & $0.15^{\mathrm{abcd}}$ & $49.2^{\text {bcdef }}$ \\
\hline & SR52 & $60.67^{\text {bcd }}$ & $250.7^{\mathrm{abcd}}$ & $0.243^{\mathrm{bcd}}$ & $0.3467^{\mathrm{abc}}$ & $0.14^{\text {abcde }}$ & $47.3^{\text {bcdef }}$ \\
\hline P24 & Land A & $53.33^{\text {de }}$ & $234.3^{\text {bcd }}$ & $0.2288^{\mathrm{bcd}}$ & $0.2^{\mathrm{gh}}$ & $0.1267^{\text {bcde }}$ & $43.3^{\text {cdef }}$ \\
\hline \multirow[t]{3}{*}{$25 \mathrm{FC}$} & Land B & $62.67^{\mathrm{bcd}}$ & $198.7^{\mathrm{d}}$ & $0.3204^{\mathrm{ab}}$ & $0.2567^{\text {cdefgh }}$ & $0.12^{\text {bcde }}$ & $33.4^{\mathrm{ef}}$ \\
\hline & SC701 & $57.33^{\text {bcd }}$ & $294.7^{\mathrm{a}}$ & $0.1942^{\mathrm{d}}$ & $0.27^{\text {bcdefgh }}$ & $0.1467^{\text {abcde }}$ & $61^{\mathrm{abc}}$ \\
\hline & SR52 & $58.33^{\mathrm{bcd}}$ & $206.3^{\mathrm{d}}$ & $0.289^{\mathrm{abcd}}$ & $0.36^{\mathrm{ab}}$ & $0.0833^{\mathrm{de}}$ & $34.6^{\mathrm{ef}}$ \\
\hline Unprimed & Land A & $58.67^{\text {bcd }}$ & $215.7^{\mathrm{d}}$ & $0.2721^{\text {bcd }}$ & $0.21^{\text {fgh }}$ & $0.1333^{\text {abcde }}$ & $44.3^{\text {cdef }}$ \\
\hline \multirow[t]{3}{*}{$75 F C$} & Land B & $63 b^{c d}$ & $226.7^{\text {cd }}$ & $0.2783^{\mathrm{bcd}}$ & $0.1967^{\mathrm{gh}}$ & $0.1267^{\text {bcde }}$ & $37.5^{\mathrm{def}}$ \\
\hline & SC701 & $62.67^{\text {bcd }}$ & $284.7^{\mathrm{ab}}$ & $0.2243^{\mathrm{bcd}}$ & $0.29^{\text {bcdefgh }}$ & $0.1367^{\text {abcde }}$ & $59.5^{\mathrm{abc}}$ \\
\hline & SR52 & $53.33^{\text {cde }}$ & $217^{\mathrm{cd}}$ & $0.2459^{\text {bcd }}$ & $0.3267^{\mathrm{abcd}}$ & $0.09^{\mathrm{de}}$ & $41.7^{\text {cdef }}$ \\
\hline $\mathrm{P} 12$ & Land A & $65^{\mathrm{abcd}}$ & $296.7^{\mathrm{a}}$ & $0.2233^{\text {bcd }}$ & $0.2233^{\text {efgh }}$ & $0.18^{\mathrm{ab}}$ & $59.9^{\mathrm{abc}}$ \\
\hline \multirow[t]{3}{*}{$75 \mathrm{FC}$} & Land B & $57.67^{\text {bcd }}$ & $199^{\mathrm{d}}$ & $0.2941^{\text {abcd }}$ & $0.2467^{\text {defgh }}$ & $0.1133^{\text {bcde }}$ & $36.1^{\text {def }}$ \\
\hline & SC701 & $63.33^{\text {bcd }}$ & $250.7^{\mathrm{abcd}}$ & $0.2555^{\mathrm{bcd}}$ & $0.3033^{\text {abcdef }}$ & $0.1633^{\mathrm{abc}}$ & $61.3^{\mathrm{abc}}$ \\
\hline & SR52 & $60.33^{\text {bcd }}$ & $300^{\mathrm{a}}$ & $0.203^{\text {cd }}$ & $0.2933^{\text {bcdefg }}$ & $0.2033^{\mathrm{a}}$ & $76.8^{\mathrm{a}}$ \\
\hline P24 & Land A & $65.33^{\text {bcd }}$ & $249.7^{\mathrm{abcd}}$ & $0.2834^{\mathrm{bcd}}$ & $0.2833^{\text {bcdefg }}$ & $0.1533^{\mathrm{abcd}}$ & $53.4^{\text {bcde }}$ \\
\hline \multirow[t]{3}{*}{$75 \mathrm{FC}$} & Land B & $61.67^{\mathrm{bcd}}$ & $258.7^{\mathrm{abcd}}$ & $0.239^{\text {bcd }}$ & $0.23^{\text {efgh }}$ & $0.18^{\mathrm{ab}}$ & $55.8^{\text {bcd }}$ \\
\hline & SC701 & $67^{\mathrm{abc}}$ & $300.7^{\mathrm{a}}$ & $0.2235^{\mathrm{bcd}}$ & $0.2767^{\text {bcdefg }}$ & $0.1733^{\mathrm{ab}}$ & $66.3^{\mathrm{ab}}$ \\
\hline & SR52 & $75.67^{\mathrm{a}}$ & $273.3^{\mathrm{abc}}$ & $0.2773^{\mathrm{bcd}}$ & $0.2667^{\text {bcdefgh }}$ & $0.1733^{\mathrm{ab}}$ & $65.4^{\mathrm{ab}}$ \\
\hline \multicolumn{2}{|c|}{$\operatorname{LSD}_{(\mathrm{P}=0.05)}$ Var*Priming*FC } & 12.159 & 57.24 & 0.10798 & 0.09336 & 0.07179 & 20.68 \\
\hline
\end{tabular}

$\overline{\text { FC }}=$ Field Capacity. Numbers with different letters in the same column differ significantly at LSD $(P=0.05)$.

0.05) on shoot length (Table 2), priming, on its own, had a highly significant effect $(P<0.001)$ on shoot length. There were no differences in root and shoot dry mass (Table 2).

\subsubsection{Leaf Area}

Leaf area development showed no significant three way interaction $(P>0.05)$ between variety, priming and field capacity (Table 2). Field capacity had a highly significant effect $(P<0.001)$ on leaf area (Table 2), reducing it by about $23 \%$ under water stress. Nonetheless, priming had a significant effect $(P<$ 0.001 ) on leaf area (Table 2); leaf area increased by $33.8 \%$ and $29 \%$ in response to priming seeds for 12 and 24 hours. Landraces increased their leaf area under water stress (25\% FC) by 34\% (P12) and 6.5\% (P24) while the hybrids increased by $48.5 \%$ (P12) and $47 \%$
(P24), respectively.

\section{Discussion}

Priming of seed has been effectively used to enhance the vigour and emergence of seedlings under both optimal [28, 29] and sub-optimal conditions [30, 31]. The objective of this study was to determine whether or not hydropriming can be used to improve vigour, with respect to germination attributes and seedling emergence under water stress, in landraces and thus improve crop establishment.

Priming had a negative effect on final germination of all varieties. Rapid uptake of water during priming may have caused imbibition injury, resulting in failure of seeds to germinate. There are similar instances in the literature reporting imbibitional injury in seeds, 
including maize [32-36]. Although most of these reports show imbibitional damage at low temperatures, imbibitional damage at higher temperatures, although less severe, can also reduce germination [5].

Priming improved germination speed and reduced MGT. Primed seeds germinated faster and more uniformly than unprimed seeds. Although priming reduced root lengths in landraces, it increased shoot lengths, fresh mass and dry mass; suggesting that a greater part of seed reserves were channeled to the shoots which is crucial for early establishment and photosynthesis. Overall, priming improved vigour of the seeds, with landraces performing well when seeds were primed for 12 hours. These results are similar to others reported in literature [3].

Wahid et al. [37] observed an increase in soluble sugars concentration in response to priming sunflower achenes. They concluded that priming-induced improvements in germination and seedling growth were associated with greater substrate availability for germination. However, contrary to this expectation, results showed an unclear pattern with respect to TSS. In most instances, priming resulted in reduced substrate availability, more so in hybrids. The higher TSS in landraces may explain their positive response to priming.

Successful crop establishment determines plant density, uniformity and management options [38] and depends not only on the rapid and uniform germination of the seed, but also on the capacity of the seed to emerge under water stress [39]. Alleviating the deleterious effect of water stress at this stage can increase chances for attaining a good crop [40].

Priming increased seedling emergence under both optimum and water stress conditions. Priming for 12 hours improved emergence of the landraces at $75 \%$ FC while priming for 24 hours resulted in better emergence for all varieties at 25\% FC. Priming for 24 hours resulted in reduced MET under water stress. Priming also resulted in increased roots and shoots lengths as well as increased leaf area in the landraces. Thus, priming resulted in improved crop establishment and healthier seedlings. Ghassemi-Golezani et al. [14] reported that hydropriming improved seedling emergence rate and percent in lentil; Harris et al. [3] reported enhanced seedling establishment and early vigour of upland rice, maize and chickpea after hydropriming; Kibite and Harker [41] reported that seed hydration improved uniformity of seedling emergence of wheat, barley and oat seeds.

\section{Conclusion}

Good crop establishment is a prerequisite for successful crop production especially under water stress conditions. Seeds responded better to priming for 12 hours when conditions were optimum while priming for 24 hours improved emergence, reduced MET and improved seedling characteristics under water stress. Farmers may use hydro-priming, combined with a slightly higher seeding rate, when planting early and late in the season. Hydro-priming maize landraces for various periods of time may be used a low-cost technology to enhance emergence and vigour characteristics of landraces under both optimum and water stress conditions. However, there is need for further research to evaluate whether these initial benefits may contribute to improved yields under water stress.

\section{Acknowledgments}

The authors are grateful to the Water Research Commission (WRCK5/1771/4) for financially supporting this work.

\section{References}

[1] J.L. Monteith, J. Elston, Performance and productivity of foliage in the field, in: J.E. Dale, F.L Milthorpe (Eds.), The Growth and Functioning of Leaves, Cambridge University Press, 1983, pp. 409-518.

[2] J.K. Itabari, P.J. Gregory, R.K. Jones, Effects of temperature, soil water status and depth of planting on germination and emergence of maize (Zea mays L.) adapted to semi-arid Eastern Kenya, Exp. Agric. 29 (1993) 351-364. 
[3] D. Harris, A. Joshi, P.A. Khan, P. Gothkar, P.S. Sodhi, On-farm seed priming in semi-arid agriculture development and evaluation in maize, rice and chickpea in India using participatory methods, Exp. Agric. 35 (1999) 15-29.

[4] C.H. Matarira, J.C. Makadho, M. Mukahanana-Sangarwe, Vulnerability and Adaptation of Maize Production to Climate Change in Zimbabwe, Ministry of Environment and Tourism, Zimbabwe, 2004.

[5] W.E. Finch-Savage, K.C. Dent, L.J. Clark, Soak conditions and temperature following sowing influence the response of maize (Zea mays L.) seeds to on-farm priming (pre-sowing seed soak), Field Crops Res. 90 (2004) 361-374.

[6] D. Harris, The effects of manure, genotype, seed priming, depth and date of sowing on the emergence and early growth of Sorghum bicolor (L.) Moench in semi-arid Botswana, Soil Till. Res. 40 (1996) 73-88.

[7] R. Foti, K. Abureni, A. Tigere, J. Gotosa, J. Gere, The efficacy of different seed priming osmotica on the establishment of maize (Zea mays L.) caryopses, J. Arid Environ. 72 (2008) 1127-1130.

[8] W.J. Heydecker, J. Higgins, K. Gulliver, Accelerated germination by osmotic seed treatment, Nature 246 (1973) 42-46.

[9] M.B. McDonald, Seed priming, in: M. Black, J. D. Bewley, (Eds.), Seed Technology and Its Biological Basis, Sheffield Academic Press, Sheffield, UK, 2000, pp. 287-325.

[10] M. Ashraf, M.R. Foolad, Pre-sowing seed treatment-a shotgun approach to improve germination growth and crop yield under saline and none-saline conditions, Advan. Agron. 88 (2005) 223-271.

[11] K.Y. Chiu, C.L. Chen, J.M. Sung, Effect of priming temperature and storability of primed sh-2 sweet corn seed, Crop Sci. 42 (2002) 1996-2003.

[12] A.L. Kao, T.Y. Chang, S.H. Chang, J.C. Su, C.C. Yang, Characterization of a novel Arabidopsis protein family AtMAPR homologous to 25-Dx/IZAg/Hpr6.6 proteins, Bot. Bull. Acad. Sin. 46 (2005) 107-118.

[13] L. Windauer, A. Altuna, R. Benech-Arnold, Hydrotime analysis of Lesquerella fendleri seed germination responses to priming treatments, Indus. Crop Prod. 25 (2007) 70-74.

[14] K. Ghassemi-Golezani, P. Sheikzadeh-Mosadeggh, M. Valizadeh, Effects of hydropriming duration and limited duration on field performance of chick-pea, Research Journal of Seed Science 1 (2008) 34-40.

[15] A.S. Basra, R. Dhillon, C.P. Malik, Influence of seed pre-treatment with plant growth regulators on metabolic alterations of germinating maize embryos under stressing temperature regimes, Ann. Bot. (London) 64 (1989)
37-41.

[16] K.D. Subedi, B.L. Ma, Seed priming does not improve corn yield in a humid temperate environment, Agron. J. 97 (2005) 211-218.

[17] R.P. Nagar, M.I. Dadlan, S.P. Sharama, Effect of hydropriming on field emergence and crop growth of maize genotypes, Seed Res. 26 (1998) 1-5.

[18] D. Harris, B.S. Raghuwanshi, J.S. Gangwar, S.C. Singh, K.D. Joshi, A. Rashid, P.A. Hollington, Participatory evaluation by farmers of 'on-farm' seed priming in wheat in India, Nepal and Pakistan, Exp. Agric. 37 (2001) 403-415.

[19] J.R.J. Rowland, Dryland Farming in Africa, Macmillan Press Limited, London, 1993.

[20] T. Mabhaudhi, A.T. Modi, Early establishment performance of local and hybrid maize under two water stress regimes, in: A. Sessay, P.L. Greenfield (Eds.), Proceedings of a Symposium on Agronomy and Water-Use of Underutilised, Indigenous and Traditional Crops, S.A.J. Plant Soil. 4 (2010) 299-304.

[21] International Seed Testing Association (ISTA), Handbook on Seedling Evaluation, 3rd ed., 2003.

[22] Association of Official Seed Analysts (AOSA), Seed Evaluation Handbook, Contribution No. 35, 1992.

[23] R.A. Ellis, E.H. Roberts, The quantification of ageing and survival in orthodox seeds, Seed Sci. Technol. 9 (1981) 373-409.

[24] J.D. Maguire, Speed of germination- aid in selection and evaluation for seedling emergence and vigour, Crop Sci. 2 (1962) 176-177.

[25] L.H. Aung, D.M. Obenland, L.G. Houck, Conditioning and heat treatments influence flavedo soluble sugars of lemon, J. Hort. Sci. Biotech. 73 (1998) 399-402.

[26] L.H. Aung, J.F. Jenner, D.C. Fouse, L.G. Houck, Postharvest conditioning temperatures and fruit maturity on flavedo soluble sugars of coastal and desert lemons, J. Hort. Sci. Biotech. 74 (1999) 288-292.

[27] J.D. Bewley, M. Black, Seeds: Physiology of Development and Germination, Plenum, New York, 1994.

[28] I. Demir, M.A. Van De Venter, The effect of priming treatment on the performance of water melon (Citrullus lanatus) seeds under temperature and osmotic stress, Seed Sci. Technol. 27 (1999) 871-875.

[29] M. Farooq, S.M.A. Basra, A. Wahid, Priming of field-sown rice seed enhances germination, seedling established, allometry and yield, Plant Growth Regul. 49 (2006) 285-294.

[30] A. Wahid, A. Shabbir, Induction of heat stress tolerance in barley seedlings by pre-sowing seed treatment with glycinebetaine, Plant Growth Regul. 46 (2005) 133-141.

[31] A. Wahid, M. Parveen, S. Gelani, S.M.A. Basra, Pre-treatment of seeds with $\mathrm{H}_{2} \mathrm{O}_{2}$ improves salt tolerance 
of Maize Landraces under Water Stress?

of wheat seedling by alleviation of oxidative damage and expression of stress proteins, J. Plant Physiol. 164 (2007) 283-294.

[32] B.M. Pollock, Imbibition temperature sensitivity of lima beans controlled by initial seed moisture, Plant Physiol. 44 (1969) 907-911.

[33] J.P. Cal, R.L. Obendorf, Imbibitional chilling injury in Zea mays L. altered by initial kernel moisture and maternal parent, Crop Sci. 12 (1972) 369-373.

[34] A.A. Powell, S. Mathews, The damaging effect of water on dry pea embryos during imbibition, J. Exp. Bot. 29 (1978) 1215-1229.

[35] A.G. Taylor, J. Prusinski, H.J. Hill, M.D. Dickson, Influence of seed hydration on seedling performance, Hort. Technol. 2 (1992) 336-344.

[36] S. Bedi, A.S. Basra, Chilling injury in germinating seeds: basic mechanisms and agricultural implications, Seed Sci. Res. 3 (1993) 219-229.
[37] A. Wahid, A. Noreen, S.M.A. Basra, S. Gelani, M. Farooq, Priming induced metabolic changes in sunflower (Helianthus annuus) achenes improve germination and seedling growth, Bot. Studies. 49 (2008) 343-350.

[38] Z. Cheng, K.J. Bradford, Hydrothermal time analysis of tomato seed germination responses to priming treatments, J. Exp. Bot. 33 (1999) 89-99.

[39] R.A. Fischer, N.C. Turner, Plant productivity in the arid and semi-arid zones, Ann. Rev. Plant Physiol. 29 (1978) 277-317.

[40] M. Ashraf, H. Rauf, Inducing salt tolerance in maize (Zea mays L.) through seed priming with chloride salts, growth and ion transport at early growth stages, Acta Physiol. Plant 23 (2001) 407-414.

[41] S. Kibite, K.N. Harker, Effects of seed hydration on agronomic performances of wheat, barley and oats in central Alberta, Can. J. Plant Sci. 71 (1991) 515-518. 